\title{
PROFIL VITAMIN D PADA PASIEN ASMA DAN NON-ASMA DEWASA DI SURABAYA
}

\author{
Rivan Virldano Suryadinata*, Amelia Lorensia**, Anugrah Putri Aprilia*** \\ *Departemen Ilmu Kesehatan Masyarakat, Fakultas Kedokteran, Universitas Surabaya \\ (UBAYA). \\ ** Departemen Farmasi Klinis, Fakultas Farmasi Universitas Surabaya (UBAYA). \\ ${ }^{* * *}$ Mahasiswa Program Studi Apoteker, Fakultas Farmasi Universitas Surabaya (UBAYA) \\ Alamat Korespondensi: \\ Rivan Virldano Suryadinata \\ Email: rivan.virldano.suryadinata@gmail.com
}

\begin{abstract}
Asthma is a chronic inflammatory disease on respiratory tract, where airflow are retricted dan chronic inflammation result in bronchial epithelium damage. Pathogenesis mechanism of asthma is influenced by vitamin $D$ as an immunomodulator. The low vitamin $D$ levels can trigger asthma exacerbations. The study aimed to determine the levels of vitamin $D$ from blood sample in astmatic young adult in compared to non astmatics, to identify the risk of vitamin D deficiency, that can aggravate asthma symptoms. The study used an observational analytic cross sectional design. Subjects were chosen through a purposive sampling method. Population was young adults in Surabaya. Subjects were 26 asthmatic patientsdan 26 non-asthmatic young adult in South Surabaya that fulfilled inclusion dan exclusion criteria. The study was conducted in May 2015 to July 2016. The results showed vitamin D levels in the asthma group $24.5 \pm 2.95$ while in the non-asthma group $20.52 \pm 2.47$. All respondents in both groups had vitamin D levels $>30 \mathrm{ng} / \mathrm{mL}$ (normal value), dan there was significant difference between levels of vitamin $D$ in asthma dan non-asthma patients $(p<0.05)$. Therefore, increasing knowledge about the importance of vitamin D should be done, because it can change behavior through lifestyle, diet dan physical activity in the community.
\end{abstract}

Keywords: asthma, vitamin D

\begin{abstract}
ABSTRAK
Asma merupakan proses inflamasi kronik saluran napas, terjadi keterbatasan aliran udara dan peningkatan respons inflamasi kronik menyebabkan kerusakan epitel bronkus. Mekanisme patogenesis asma dipengaruhi juga oleh vitamin D sebagai imunomodulator. Kadar vitamin D yang rendah dapat memicu terjadinya perburukan asma. Penelitian ini bertujuan untuk mengetahui kadar vitamin D dalam darah pasien asma dewasa muda sebagai identifikasi risiko defisiensi vitamin $\mathrm{D}$ yang dapat memperparah gejala asmanya, dibandingkan dengan kadar vitamin D non-asma. Penelitian ini adalah observasional analitik dengan metode cross sectional. Pengumpulan sampel dengan teknik purposive sampling. Populasi penelitian ini adalah masyarakat dengan usia dewasa muda di Surabaya. Subjek penelitian berjumlah 26 pasien dewasa asma dan 26 pasien dewasa non asma di Surabaya Selatan yang memenuhi kriteria inklusi dan eksklusi. Penelitian dilakukan pada bulan Mei 2015 sampai dengan Juli 2016 di daerah Surabaya Selatan, dengan cara pengambilan darah untuk melihat kadar vitamin D dalam darah. Hasil penelitian menunjukkan rerata kadar vitamin D pada kelompok asma 24,5 $\pm 2,5$ sedangkan pada kelompok non asma 20,5 $\pm 2,5$. Semua responden pada kedua kelompok memiliki kadar vitamin D di bawah normal yaitu $>30 \mathrm{ng} / \mathrm{mL}$ dan terdapat perbedaan signifikan antara kadar vitamin D pada pasien
\end{abstract}


asma dan non asma $(\mathrm{p}<0,05)$. Oleh karena itu, diperlukan peningkatan pengetahuan akan pentingnya vitamin $\mathrm{D}$, sehingga terjadi perubahan perilaku melalui perbaikan gaya hidup, pola makan dan aktivitas fisik pada masyarakat.

Kata kunci: asma, vitamin D

\section{PENDAHULUAN}

Asma adalah penyakit pada saluran napas yang ditandai dengan peradangan saluran napas kronis yang dipengaruhi oleh riwayat gejala pernapasan seperti mengi, sesak napas, sesak dada dan batuk yang bervariasi dari waktu ke waktu dan intensitas, bersama-sama dengan variabel keterbatasan aliran udara ekspirasi (Global Initiative for Asthma, 2015). Penyakit asma menjadi masalah yang sangat dekat dengan masyarakat karena jumlah populasi yang menderita asma semakin bertambah. The Global Asthma Report (2014), melaporkan jumlah penderita asma di dunia mencapai 334 juta. Prevalensi asma di berbagai negara berkisar antara 1-18\% dari populasi (Global Initiative for Asthma, 2015). Indonesia memiliki prevalensi asma sekitar 2-5\% dari total penduduk Indonesia dan terjadi peningkatan prevalensi tiap tahunnya hingga mencapai 5,4\% (Oemiati et al., 2010).

Gejala yang ditimbulkan akibat asma dapat bersifat ringan dan tidak mengganggu aktivitas, namun dapat pula bersifat menetap dan berpengaruh dalam aktivitas seharihari. Apabila penyakit asma tidak ditangani dengan baik maka akan dapat menimbulkan berbagai gejala klinis yang bervariasi tergantung derajat keterbatasan aliran udara asma terjadi, sehingga menyebabkan ketidakmampuan mengenali dan mencegah pencetus yang dapat menyebabkan jalan napas terganggu, mengancam jiwa dan dapat menimbulkan serangan asma, kegagalan pernapasan bahkan kematian (WHO, 2003).

Penyakit asma merupakan proses inflamasi kronik saluran napas, terjadi keterbatasan aliran udara dan peningkatan respons inflamasi kronik menyebabkan kerusakan epitel bronkus sehingga terjadi perubahan struktural dan fungsional. Faktor risiko terjadinya asma diakibatkan faktor pejamu (host factor) dan faktor lingkungan. Berbagai faktor penjamu yaitu genetik, asma, alergik, hipereaktiviti bronkus, jenis kelamin dan ras (PDPI, 2004).

Patofisiologi asma terdiri dari fase awal yang ditdanai dengan kontriksi saluran napas bronkial dan bronkospasme yang diikuti oedema saluran pernapasan dan produksi mukus berlebihan. Bronkospasme dapat disebabkan peningkatan pelepasan mediator inflamasi seperti histamin, prostagladanin dan bradikinin yang dapat memicu bronkokonstriksi daripada inflamasi. Fase akhir terjadi setelah beberapa jam dari munculnya onset gejala awal dan bermanifestasi sebagai respon inflamasi. Mediator utama dari inflamasi selama respons asmatik adalah sel darah merah (eosinofil) yang menstimulasi degradasi sel mast dan pelepasan substansi yang menyerang sel darah putih lain pada area tersebut (Kelly dan Sorkness, 2011).

Mekanisme patogenesis asma dipengaruhi juga oleh vitamin D sebagai imunomodulator, yang berperan menghambat fungsi limfosit $\mathrm{T}$, baik secara langsung maupun melalui efek pada antigen presenting sel (APC) dan menghambat produksi interleukin-17 (IL-17), yang merupakan sitokin proinflamasi yang diproduksi oleh sel T khususnya Th17 yang berperan dalam respons inflamasi yang didominasi oleh neutrofil (Park, 2010; Mahon et al., 2003).

Kulit memiliki kapasitas yang besar untuk menghasilkan vitamin D dan paparan sekitar 20\% dari permukaan tubuh baik terhadap sinar matahari langsung sangat efektif dalam meningkatkan konsentrasi plasma dari $25(\mathrm{OH}) \mathrm{D}$ pada dewasa muda dan dewasa tua (Holick, 2004). 
Hubungan antara paparan kulit terhadap sinar matahari ditentukan dari panjang gelombang yang sesuai dan jaringan subkutan untuk mensintesis vitamin D. Misalnya, di Cincinnati (lintang $38^{\circ} \mathrm{N}$ ) selama musim semi, musim panas, dan musim gugur, bayi dengan ASI eksklusif yang berusia kurang dari enam bulan menghabiskan 20 menit sehari di jendela agar terkena tangan dan wajah sehingga dapat mempertahankan konsentrasi $25(\mathrm{OH}) \mathrm{D}$ di atas $27.5 \mathrm{nmol} / 1$. Paparan sinar matahari selama 5-15 menit antara pukul 10.00 dan 15.00 selama musim semi, musim panas, dan musim gugur pada daerah dengan lintang di atas $37^{\circ}$ dapat mencukupi kebutuhan vitamin D (Holick, 2004).

Metabolisme vitamin D diawali dengan Ergostreol yang ditemukan pada tanaman dan 7-dehidrokolesterol pada tubuh hewan. Ergostreol berbeda dari 7-dehidrokolesterol hanya pada rantai sampingnya, yang bersifat tidak jenuh dan mengandung gugus metil ekstra. Sinar ultraviolet memutus cincin B kedua senyawa. Ergokalsiferol (Vitamin D2) dapat dibuat dari tanaman m, sedangkan pada hewan, 7-dehidrokolesterol akan membentuk kolekalsiferol (Vitamin D3) pada kulit yang terpajan. Vitamin D2 dan Vitamin D3 memiliki potensi yang sama.

Fungsi utama dari vitamin D manusia adalah untuk mempertahankan konsentrasi serum kalsium dengan cara meningkatkan kemampuan usus kecil untuk menyerap kalsium pada makanan, serta meningkatkan penyerapan fosfor, namun konsentrasi fosfor dalam darah tidak diatur oleh vitamin D melainkan tergantung dari ekskresi ginjal (Baghurst, 2005).

Vitamin D juga berfungsi mempertahankan kalsium darah pada tingkat jenuh sehingga dapat disimpan dalam tulang sebagai kalsium hidroksiapatit. Ketika diet kalsium tidak mencukupi untuk memenuhi kebutuhan tubuh, maka 1,25dihydroxyvitamin $\mathrm{D}[1,25(\mathrm{OH}) 2 \mathrm{D}$ atau calcitriol] yang merupakan bentuk aktif dari Vitamin D bersama-sama dengan hormon paratiroid, melakukan mobilisasi sel induk dalam sumsum tulang untuk menjadi osteoklas dewasa yang dapat meningkatkan simpanan kalsium dari tulang. Namun, kapasitas yang terbatas untuk melakukan mobilisasi kalsium dari tulang untuk memiliki pengaruh yang signifikan terhadap kadar kalsium darah (Baghurst K., 2005).

Selain itu, Vitamin D dengan bentuk 1,25 $(\mathrm{OH})$ 2D bertindak dengan hormon paratiroid dan kalsitonin untuk mempertahankan konsentrasi kalsium pada plasma dalam kisaran normal. Hal ini dicapai dengan mengatur efisiensi usus halus untuk menyerap kalsium dari diet, dengan mobilisasi kalsium dari tulang dan dengan reabsorpsi tubular kalsium dalam ginjal. Paratiroid Hormon dan 1,25 (OH) 2D bersama-sama merangsang osteoblas untuk menginduksi pematangan pra osteoklas menjadi osteoklas, sehingga meningkatkan resorpsi tulang (Williams et al., 2007).

Sumber utama vitamin $D$ bagi manusia adalah paparan sinar matahari. Efisiensi konversi 7-dehydrocholesterol ke vitamin D3 sangat tergantung pada waktu, hari, musim tahun, lintang, warna kulit dan usia. Bila sedikit vitamin D yang didapat secara alami maka dapat diperoleh dari pasokan makanan. Sumber makanan utama vitamin D adalah ikan, hati sapi dan kuning telur. Di Amerika Serikat dan Kanada, sumber makanan utama yang mengandung vitamin D ini sangatlah banyak, termasuk susu sapi. Sumber daya yang ada pada negara masing-masing sangat berpengaruh terhadap asupan vitamin $\mathrm{D}$ di masyarakat (Abrams dan Atkinson, 2009).

Sebuah penelitian di Kanada yang melibatkan pasien asma berusia 13-69 tahun menemukan bahwa seseorang yang kekurangan vitamin D berisiko $\geq 50 \%$ lebih besar terserang asma dibandingkan seseorang dengan kadar vitamin D yang cukup (Niruban et al., 2015). Survey yang dilakukan pada anak di Indonesia telah menunjukkan 49,3\% mengalami insufisiensi sedangkan 45,1\% mengalami defisiensi Vitamin D (Ernawati dan Sdanjaja, 2011) 
Kadar vitamin $\mathrm{D}$ yang rendah dapat memicu terjadinya perburukan asma. Pada sejumlah penelitian yang telah dilakukan menunjukkan bahwa defisiensi vitamin D berkaitan dengan inflamasi saluran napas (Maalmi et al., 2012; Sutherldan et al., 2010), hiperresponsif saluran napas (Sutherldan et al., 2010), penurunan fungsi paru (Maalmi et al., 2012; Sutherldan et al., 2010; Brehm et al., 2010; Li et al., 2011) kontrol asma yang buruk, tingginya rawat inap serta eksaserbasi asma (Chinellato et al., 2011). Kekurangan vitamin D yang berisiko menyebabkan defisiensi vitamin $\mathrm{D}$, dapat diketahui dengan pemeriksaan kadar vitamin D dalam darah. Jumlah vitamin D seseorang dapat diketahui dengan nilai kadar vitamin D dalam darah melalui pengukuran kadar 25-hydroxyvitamin D dalam darah. Kadar 25-hydroxyvitamin $\mathrm{D}$ dalam darah dibagi menjadi tiga golongan: kadar $>30 \mathrm{ng} / \mathrm{mL}$ (75 nmol/L) digolongkan normal; kadar 20-30 ng/mL (50-75 nmol/L) digolongkan sebagai insufisiensi vitamin D; sedangkan kadar $<20 \mathrm{ng} / \mathrm{mL}(<50 \mathrm{nmol} / \mathrm{L})$ digolongkan sebagai defisiensi vitamin D (Niruban et al., 2015).

Defisiensi vitamin D bisa terjadi karena kurangnya nutrisi vitamin D, kurangnya paparan sinar matahari, obesitas, gangguan pada hati, dan ginjal (Holick, 2010; Plum et al., 2010). Sumber utama vitamin $\mathrm{D}$ berasal dari sinar matahari berasal dari radiasi matahari ultraviolet (UV) B (UVB) yang mengkonversi 7-dehydrocholesterol di kulit menjadi previtamin D3 dan kemudian menjadi vitamin D3. Pada makanan, vitamin D paling banyak ditemukan dalam minyak ikan (contoh: ikan salmon dan makarel), bijibijian dan produk susu (Lange et al., 2009; Holick et al., 2010).

Di Indonesia sendiri, peran vitamin D pada pengobatan asma belum menjadi perhatian. Vitamin D diharapkan dapat menjadi pertimbangan untuk pengobatan asma secara alamiah dan menimbulkan efek samping. Pengobatan asma selama ini dengan pengobatan sintetik, memerlukan pemantauan pengobatan yang rasional (Lorensia et al., 2011; Lorensia et al., 2012), karena dapat berisiko terjadinya efek samping yang justru memperparah kondisi pasien atau bahkan meningkatkan biaya pengobatan (Lorensia et al., 2013a; Lorensia et al., 2013 ${ }^{\mathrm{b}}$ ). Padahal Indonesia sebagai negara tropis di Asia memiliki potensi paparan sinar matahari yang sangat besar. Oleh karena itu, penelitian ini bertujuan untuk mengetahui kadar vitamin D dalam darah pasien asma dewasa muda sebagai identifikasi risiko defisiensi vitamin D yang dapat memperparah gejala asmanya, dibdaningkan dengan kadar vitamin D nonasma.

\section{METODE PENELITIAN}

\section{Desain Penelitian}

Penelitian ini merupakan penelitian observasional analitik dengan pendekatan cross sectional dimana subjek penelitian akan diukur kadar vitamin D dalam darah.

\section{Variabel Penelitian}

Variabel penelitian berupa kadar vitamin D dalam darah. Cara yang paling akurat untuk mengukur banyak vitamin D dalam tubuh adalah tes darah 25-hidroksi vitamin D (25 OH vitamin D) (Jacobsen, 2016; Holick, 2011).

Besar sampel asma dan non-asma pada masing-masing kelompok adalah 26 orang. Pengukuran kadar $25 \mathrm{OH}$ vitamin D dalam darah dilakukan dengan pengambilan sampel darah vena pada bagian lipatan siku sebesar $3 \mathrm{ml}$ oleh tenaga kesehatan di RSAL dr. Oepomo, Surabaya. Setelah pengambilan darah, sampel darah tersebut diletakkan dalam tabung vacutainer, kemudian dilakukan sertrifuge untuk memperoleh serum darah. Serum darah diletakkan pada cup serum/ PCR tube, yang kemudian dibawa ke Laboratorium Biokimia Universitas Airlangga, Surabaya untuk dilakukan analisa kadar vitamin D. 


\section{Populasi dan Sampel}

Populasi penelitian ini adalah masyarakat dengan usia dewasa muda di Surabaya. Subjek (sampel) penelitian pasien asma dan non asma diperoleh di Surabaya Selatan yang memenuhi kriteria inklusi dan eksklusi. Kriteria inklusi pada penelitian adalah Pasien dewasa berusia $\geq 18-25$ tahun (National Center for Chronic Disease Prevention dan Health Promotion, 2011) yang bersedia menjadi sampel penelitian dengan mengisi informed consent terlebih dahulu.

Pasien dengan riwayat asma/ nonasma tidak boleh memiliki penyakit penyerta lain yang memengaruhi system pernafasan, seperti: PPOK (Penyakit Paru Obstruksi kronis) dan tuberculosis, selain itu tidak memiliki penyakit yang dapat memengaruhi kadar vitamin D dalam darah yang dapat memengaruhi kemampuan usus untuk menyerap vitamin D dari makanan yang dikonsumsi seperti: Gangguan pada saluran pencernaan (penyakit Crohn, cystic fibrosis, dan penyakit celiac) (Jacobsen, 2016; Tsiaras dan Weinstock, 2011), Penyakit ginjal kronis yang tidak dapat mengkonversi vitamin D menjadi bentuk aktifnya (Jacobsen, 2016; Tsiaras dan Weinstock, 2011) dan mengonsumsi obat rutin yang dapat memengaruhi kadar vitamin D seperti kortikosteroid (Buckley et al., 1996), orlistat (obat penurun berat badan) dan cholestyramine (obat penurun kolesterol), Fenobarbital dan fenitoin (Gough et al., 1986) dan vitamin yang larut dalam lemak (McDuffie et al., 2002; Compston, 1978).

Pasien yang merokok aktif juga tidak dapat dijadikan sampel, dikarenakan paparan rokok dapat memengaruhi kadar vitamin $\mathrm{D}$ dalam darah dan bahan kimia yang berasal dari asap tembakau dapat memengaruhi metabolisme vitamin D (Banihosseini et al., 2013).

\section{Besar Sampel}

Besar sampel dalam penelitian ini adalah minimal 26 orang. Metode perhitungan besar sampel menggunakan persamaan dari rumus Medical Statistic (Naing et al., 2008):

$$
\mathrm{n}=\frac{\mathrm{Z}^{2} \cdot \mathrm{P} \cdot \mathrm{Q}}{\mathrm{d}^{2}}
$$

Bila:

$$
\begin{aligned}
& Z=1,96 \\
& P=0.017(\text { RISKESDAS, 2008) } \\
& Q=1-P=1-0,0262=0,983 \\
& d=0,05
\end{aligned}
$$

Maka besar sampel penelitian (n) minimal tiap kelompok dalam penelitian ini adalah 25,67 $\sim 26$ orang.

\section{Metode Pengumpulan Data dan Analisa Data}

Subjek penelitian yang memenuhi kriteria akan dilakukan wawancara untuk mengetahui umur, jenis kelamin, dan riwayat pengobatan. Setelah itu dilanjutkan dengan pengambilan darah untuk mengetahui kadar vitamin D dalam tubuh. Hasil penelitian ini akan dipaparkan secara narasi dan deskriptif. Setelah itu dilakukan uji perbandingan antara pasien asma dan non sama dengan menggunakan uji T-test.

\section{HASIL}

Penelitian dilakukan pada bulan Mei 2015 sampai dengan Juli 2016 di daerah Surabaya Selatan.

\section{Karakteristik Subjek Penelitian}

Karakteristik sampel penelitian (responden) dikelompokkan berdasarkan umur, jenis kelamin, dan riwayat pengobatan asma. Umur responden diketahui saat wawancara dilakukan. Seluruh responden merupakan remaja akhir (17-25 tahun). 
Kategori jenis kelamin dibedakan berdasarkan laki-laki dan perempuan. Distribusi responden menurut umur dan jenis kelamin dapat dilihat pada tabel 1 .

Tabel 1. Distribusi Frekuensi Subjek Penelitian

\begin{tabular}{llllll}
\hline \multirow{2}{*}{ Kategori } & \multicolumn{4}{c}{ Frekuensi } \\
\cline { 3 - 6 } & & $\mathbf{n}_{\text {(Asma) }}=\mathbf{2 6}$ & $\begin{array}{c}\mathbf{n}_{\text {(Non Asma) }} \\
=\mathbf{2 6}\end{array}$ \\
\hline Jenis & Laki-laki & 7 & $(26,9 \%)$ & 6 & $(23,1 \%)$ \\
\cline { 2 - 6 } Kelamin & Perempuan & 19 & $(73,1 \%)$ & 20 & $(76,9 \%)$ \\
\hline Usia & Remaja & 26 & $(100 \%)$ & 26 & $(100 \%)$ \\
(tahun) & Akhir & & & & \\
Dekpes & $(17-25$ & & & & \\
RI & tahun) & & & & \\
$(2009)$ & & & & & \\
\hline
\end{tabular}

Hasil penelitian menunjukkan seluruh responden merupakan remaja akhir (17-25 tahun). Jumlah responden asma dan non asma terbanyak adalah wanita, yaitu sebesar $73,1 \%$ untuk asma dan $76,9 \%$ untuk non asma (Tabel 1).

Tabel 2. Distribusi Frekuensi Riwayat Pengobatan Responden

\begin{tabular}{|c|c|c|c|}
\hline \multicolumn{2}{|c|}{$\begin{array}{c}\text { Riwayat Pengobatan } \\
\text { Asma }\end{array}$} & \multirow{2}{*}{$\begin{array}{c}\begin{array}{c}\text { Jumlah } \\
\text { (orang) }\end{array} \\
7\end{array}$} & \multirow{2}{*}{$\begin{array}{c}\text { Persentase } \\
26,9\end{array}$} \\
\hline $\begin{array}{l}\text { Golongan } \\
\text { Obat }\end{array}$ & $\begin{array}{l}\text { Agonis } \\
\beta-2 \text { kerja } \\
\text { singkat oral } \\
\text { (NHLBI, } \\
2007 \text { ) }\end{array}$ & & \\
\hline & $\begin{array}{l}\text { Agonis } \\
\beta-2 \text { kerja } \\
\text { singkat } \\
\text { inhalasi } \\
\text { (NHLBI, } \\
\text { 2007) }\end{array}$ & 19 & 73,1 \\
\hline
\end{tabular}

Tabel 2 menjelaskan tentang jumlah responden berdasarkan riwayat pengobatan. Berdasarkan hasil penelitian responden dengan riwayat pengobatan yang menggunakan agonis $\beta-2$ kerja singkat inhalasi sebesar $73,1 \%$, dan responden dengan riwayat pengobatan yang menggunakan agonis $\beta$-2 kerja singkat oral sebanyak
$26,9 \%$. Semua sampel penelitian berada pada Step 1, sehingga semua sampel penelitian pasien asma tidak ada yang menggunakan obat asma secara rutin.

Uji Perbedaan Kadar Vitamin D dalam Darah antara Pasien Asma dan Non-Asma

Uji normalitas persebaran data dilakukan dengan menggunakan uji shapirowilk karena jumlah sampel $\leq 50$. Nilai p > 0,05 maka dapat disimpulkan bahwa data berdistribusi normal Selanjutnya akan dilakukan uji homogenitas dengan menggunakan uji Levene's. Sedangkan nilai $\mathrm{p}>0,05$ maka dapat disimpulkan bahwa sebaran data homogen, sehingga data dapat diuji dengan menggunakan analisa pooled t-test dan apabila tidak berdistribusi normal maka dapat dianalisa dengan menggunakan uji Mann Withney.

Tabel 3. Uji Normalitas Kadar Vitamin D Menggunakan Uji Shapiro-Wilk

\begin{tabular}{llcc}
\hline Variabel & Kelompok & $\mathbf{p}$ & Kesimpulan \\
\hline Kadar & Asma & 0,4 & Normal \\
\cline { 2 - 4 } Vitamin D & Non Asma & 0,1 & Normal \\
\hline
\end{tabular}

Keterangan: $p>0,05=$ sebaran data normal

Tabel 4. Uji Homogenitas Kadar Vitamin D Menggunakan Uji Levene's

\begin{tabular}{lllc}
\hline Variabel & Kelompok & $\mathbf{p}$ & Kesimpulan \\
\hline Kadar & Asma & 0,2 & Homogen \\
\cline { 2 - 2 } Vitamin D & Non Asma & & \\
\cline { 1 - 2 }
\end{tabular}

Keterangan: $p>0,05=$ sebaran data homogen

Hasil uji normalitas menunjukkan nilai $\mathrm{P}=0,4>0,05$ untuk kelompok asma dan $\mathrm{P}=$ $0,1>0,05$ untuk kelompok non asma, maka dapat disimpulkan bahwa data berdistribusi normal dan uji homogenitas menunjukkan nilai $\mathrm{P}=0,2>0,05$, maka dapat disimpulkan bahwa sebaran data homogen. sehingga data dapat diuji dengan menggunakan analisa pooled t-test. 
112 The Indonesian Journal of Public Health, Vol. 12 No. 1, Juli 2017: 106-117

Tabel 5. Uji Pooled T Test Kadar Vitamin D

\begin{tabular}{cllllcc}
\hline Variabel & Kelompok & Mean \pm SD & Min & Max & p & Kesimpulan \\
\hline \multirow{2}{*}{ Kadar Vitamin D } & Asma & $24,5 \pm 2,9$ & 19,3 & 30,2 & \multirow{2}{*}{0,000} & $\begin{array}{c}\text { Ada perbedaan } \\
\text { yang signifikan }\end{array}$ \\
\cline { 2 - 5 } & Non Asma & $20,5 \pm 2,5$ & 15,9 & 26,6 & & yang
\end{tabular}

Keterangan: $\mathrm{p}<0,05=$ Ada perbedaan yang signifikan

Tabel 6. Tabulasi Silang Kadar Vitamin D pada Pasien Asma dan Non Asma

\begin{tabular}{cccccc}
\hline \multirow{2}{*}{ Variabel } & Kelompok & \multicolumn{3}{c}{ Klasifikasi } & \multirow{2}{*}{ N } \\
\cline { 3 - 5 } & & Defisiensi & Insufisiensi & Normal & \\
\hline \multirow{4}{*}{ Kadar Vitamin D } & Asma & $2(7,7 \%)$ & $24(92,3 \%)$ & 0 & 26 \\
\cline { 2 - 5 } & Mean & $19,6 \pm 0,5$ & $24,9 \pm 2,7$ & & \\
\cline { 2 - 5 } & Non Asma & $11(42,3 \%)$ & $15(57,7 \%)$ & 0 & 26 \\
\hline
\end{tabular}

Hasil uji pooled t test pada tabel 5 menunjukkan bahwa ada perbedaan signifikan antara kadar vitamin D pada pasien asma dan non asma, di mana kadar vitamin D pada pasien asma dengan mean \pm sd $(24,5 \pm 2,95)$ lebih besar dibandingkan pada pasien non asma dengan mean \pm sd $(20,5 \pm 2,47)$.

Kategori kadar vitamin $\mathrm{D}$, dibedakan menjadi: kadar $>30 \mathrm{ng} / \mathrm{mL}(>75 \mathrm{nmol} / \mathrm{L})$ digolongkan normal; kadar 20-30 $\mathrm{ng} / \mathrm{mL}(50-75 \mathrm{nmol} / \mathrm{L})$ digolongkan sebagai insufisiensi vitamin $\mathrm{D}$; sedangkan kadar $<20 \mathrm{ng} / \mathrm{mL}(<50 \mathrm{nmol} / \mathrm{L})$ digolongkan sebagai defisiensi vitamin D (Niruban et al., 2015). Tabulasi silang kadar vitamin $D$ pada pasien asma dan non asma ditunjukkan pada tabel 6.

Pada tabel 6, hasil penelitian menunjukkan bahwa tidak ada responden asma dan non asma yang memiliki kadar vitamin D normal. Pada kelompok asma 92,3\% mengalami insufisiensi vitamin $D$, dan 7,69\% mengalami defisiensi vitamin D. Sedangkan untuk responden non asma sebanyak $57,7 \%$ mengalami insufisiensi vitamin $\mathrm{D}$, dan $42,3 \%$ mengalami defisiensi vitamin D.

Pada tabel 6 juga memperlihatkan nilai rerata pada setiap kelompok. Kelompok asma dan non asma pada klasifikasi defisiensi terdapat perbedaan signifikan, di mana rerata kelompok asma sebesar 19,6 $\pm 0,5$ dibandingkan pada kelompok non asma sebesar 18,5 $\pm 1,2$, sedangkan pada klasifikasi insufisiensi kelompok asma memiliki nilai rerata sebesar 24,9 $\pm 2,7$ dibandingkan kelompok non asma sebesar $22 \pm 2,1$.

\section{PEMBAHASAN}

Seluruh responden merupakan golongan remaja akhir (17 tahun25 tahun) berjumlah 52 orang (100\%). Angka terbesar responden asma dan non asma berjenis kelamin perempuan dengan jumlah responden asma 19 orang (73\%) dan responden non asma 20 orang (76,9\%). Responden asma yang menggunakan Agonis $\beta$-2 kerja singkat per oral sebanyak 7 orang (26,9\%), sedangkan yang menggunakan Agonis $\beta$-2 kerja per inhalasi sebanyak 19 orang $(73 \%)$.

Perempuan dapat dikatakan lebih rentan terhadap pajanan yang dapat memicu reaksi hipersensitivitas dan merespons reaksi lebih buruk dibandingkan laki-laki (Sundberg et al., 2010). Hal ini disebabkan adanya kadar estrogen yang berada dalam tubuh dapat meningkatkan degranulasi eosinofil sehingga memudahkan terjadinya serangan asma karena kadar estrogen yang tinggi dapat berperan sebagai substansi proinflamasi 
(membantu/memicu inflamasi) terutama memengaruhi sel mast di mana sel tersebut dapat memicu reaksi hipersensitivitas dengan melepaskan histamin dan mediator inflamasi lainnya (Bonds dan Midoro-Horiuti, 2013). Selain itu kadar 25(OH)D yang rendah pada tubuh manusia juga berpengaruh terhadap peningkatan risiko keparahan penyakit seperti CAD (Coronary Artery Disease) (Verdoia et al., 2015).

Hasil uji pooled t test pada tabel 5 menunjukkan bahwa ada perbedaan signifikan $\mathrm{p}=0,000(\mathrm{p}<0,05)$ antara kadar vitamin $\mathrm{D}$ pada pasien asma dan non asma, dimana kadar vitamin $\mathrm{D}$ pada pasien asma $(24,5 \pm 2,9)$ lebih besar daripada pasien non asma $(20,5 \pm 2,5)$. Namun, hasil penelitian pada kedua kelompok yaitu responden asma dan non asma tidak ada yang memiliki kadar vitamin D dalam rentang normal, bahkan sebagian besar termasuk dalam golongan defisiensi vitamin D. Hasil berbeda disampaikan oleh Kolokotroni et al (2015), dan Tamašauskienè (2015), diketahui bahwa kadar vitamin D cenderung lebih rendah pada pasien asma dibandingkan dengan nonasma dan vitamin D tidak berkaitan dengan keparahan gejala penyakit asma.

Indonesia sebagai salah satu negara tropis memiliki paparan sinar matahari yang cukup. Namun, pada kenyataannya kandungan vitamin $\mathrm{D}$ dalam tubuh masyarakat di Indonesia menunjukkan hal yang berbeda. Kadar vitamin D dalam tubuh pada penderita asma dan non asma berada di bawah nilai normal. Hal ini memperlihatkan berbagai macam faktor yang memengaruhi kadar vitamin D (Bosse, 2009).

Kadar vitamin D dapat dipengaruhi oleh faktor lingkungan. Defisiensi vitamin $\mathrm{D}$ dapat terjadi karena kurangnya nutrisi vitamin D, kurangnya paparan sinar matahari, obesitas, gangguan pada hati, dan ginjal (Holick, 2010; Plum et al., 2010). Sumber utama vitamin D berasal dari sinar matahari berasal dari radiasi matahari ultraviolet (UV) B (UVB) yang mengkonversi 7-dehydrocholesterol di kulit menjadi previtamin D3 dan kemudian menjadi vitamin D3. Pada makanan, vitamin D paling banyak ditemukan dalam minyak ikan (contoh: ikan salmon dan makarel), bijibijian dan produk susu (Lange et al., 2009; Holick et al., 2010; Weiss dan Litonjua, 2011).

Vitamin D merupakan vitamin yang larut dalam lemak dan dapat disimpan dalam tubuh. Vitamin D terdiri dari 2 macam, yang pertama disebut ergocalciferol (vitamin D2) yang dibentuk oleh radiasi ultraviolet (UV) dari ergosterol steroid tanaman, yang kedua disebut cholecalciferol (vitamin D3) yang dibentuk di kulit melalui cahaya UV pada 7-dehydrocholesterol untuk memproduksi cholecalciferol (Reeder dan Hurst. 2012).

Vitamin D diperoleh melalui kulit dalam kondisi normal, dengan mekanisme dari metabolit aktif, 1,25-dihydroxyvitamin D yang disintesis melalui ginjal dan dapat bertindak di organ lain, sehingga vitamin D dapat disebut juga dengan hormon. (Baghurst, 2005). Selain itu, vitamin D merupakan salah satu regulator penting dalam homeostasis kalsium dan fosfor. Vitamin D juga memainkan banyak peran dalam diferensiasi sel, sekresi dan metabolisme hormon, termasuk hormon parathyroid dan insulin (Allen et al., 2006).

Vitamin D3 juga dapat disintesis pada kulit manusia, pada paparan radiasi ultraviolet B (UVB) dengan panjang gelombang 290 sampai $320 \mathrm{~nm}$. Proses konversi UVBdimediasi oleh 7-dehydrocholesterol ke bentuk previtamin D3 dan isomerisasi thermal vitamin D3 yang terjadi pada epidermis. Produksi vitamin D3 di kulit tergantung dari jumlah radiasi UVB yang mencapai dermis serta ketersediaan 7dehidrokolesterol (Holick, 2004).

Vitamin D3 yang terbentuk dari 7-dehidrokolesterol dibantu oleh cahaya matahari dan Vitamin D3 (atau D2) yang berasal dari makanan akan beredar di dalam sirkulasi darah dalam keadaan terikat pada sebuah molekul globulin spesifik, yang disebut Protein Pengikat Vitamin D. Vitamin 
D3 diambil oleh hati dan dihidroksilasi pada posisi-25 oleh Vitamin D3-25-hidroksilase, yang merupakan suatu enzim pada retikulum endoplasma. 25-Hidroksivitamin D3 merupakan bentuk utama vitamin D di dalam darah dan bentuk cadangan utama di dalam hati, meskipun jaringan adiposa serta otot rangka juga sebagai tempat penyimpanan utama vitamin D. 25-Hidroksivitamin D3 akan mengalami sirkulasi enterohepatik bila dibutuhkan, dan proses ini akan mengakibatkan terjadinya defisiensi Vitamin D.

Di dalam tubulus ginjal, tulang dan plasenta, 25-Hidroksivitamin D3 dihidroksilasi lebih lanjut pada posisi 1 oleh enzim 25-Hidroksivitamin D3-1-hidroksilase, suatu enzim di mitokondria. Produk yang dihasilkan adalah 1 $\alpha$-25-Hidroksivitamin D3 (kalsitriol), yang merupakan metabolit vitamin D yang paling poten. Pembentukan produk ini diatur oleh konsentrasi vitamin D sendiri, hormon paratiroid dan fosfat serum.

Pada 25-Hidroksivitamin D3, juga dapat mengalami hidroksilasi pada posisi 24 oleh enzim mitokondria yang terdapat di dalam tubulus ginjal, kartilago, usus dan plasenta. Namun kadar produk 24,25Hidroksivitamin D3 berhubungan secara resiprokal dengan kadar serum 1,25Hidroksivitamin D3 serta secara biologis bersifat inaktif. (Murray et al., 2014).

Keracunan dari vitamin D tidak pernah terjadi walaupun terkena paparan sinar matahari yang berkepanjangan. Aktivasi termal previtamin D3 di kulit menimbulkan beberapa bentuk non-vitamin D, seperti lumisterol, tachysterol dan lain-lain. Hal ini membuat vitamin $\mathrm{D}$ dapat membatasi pembentukannya sendiri, selain itu vitamin D3 juga dapat dikonversi ke bentuk non aktif (Ross et al., 2011).

Kaitan vitamin D pada pasien asma masih belum jelas, namun vitamin D dapat melindungi dari mengembangkan infeksi saluran pernapasan yang bisa berfungsi sebagai pemicu untuk kerusakan asma.
Vitamin D dapat juga memodulasi fungsi berbagai sel kekebalan tubuh (Herr et a l., 2011).

\section{SIMPULAN}

Semua responden baik asma dan nonasma memiliki kadar vitamin D di bawah rentang terapi dan ada perbedaan signifikan antara kadar vitamin D pada pasien asma dan non asma, di mana kadar vitamin $\mathrm{D}$ pada pasien asma lebih besar dibandingkan pada pasien non asma.

Hasil penelitian yang dilakukan ini tidak lepas dari beberapa keterbatasan ataupun kekurangan. Adapun keterbatasan ataupun kekurangan dalam penelitian ini adalah sebagai berikut: (a) Adanya beberapa faktor yang memengaruhi hasil penelitian yang tidak dapat dikendalikan, seperti faktor emosi, faktor sosial, dan faktor ekonomi, berat badan; (b) Paramater untuk penilaian $25(\mathrm{OH})$ vitamin D masih terbatas, sehingga disarankan untuk penelitian dilakukan penambahan jumlah sampel dan pemeriksaan berbagai macam kadar vitamin $\mathrm{D}$.

\section{DAFTAR PUSTAKA}

Abrams, S., Atkinson, S., Jones, G., Mayne, S.T. 2009. Vitamin D dan Calcium: A Systematic Review of Health Outcomes. Evidence Report /Technology Assessment. 183.

Allen, L., Benoist, B., Dary, O., Hurrell, R. 2006. Guidelines on Food Fortification with Micronutrients. Food dan Agricultural Organization of the United Nations, WHO.

Baghurst, K. 2005. Nutrient Reference Values for Australia dan New Zealdan. National Health dan Medical Research. National Health dan Medical Research Council, Department of Health ang Aging, Australian Government.

Banihosseini, S.Z., Baheiraei, A., Shirzad N., Heshmat, R., Mohsenifar, A. 2013. The effect of cigarette smoke exposure on vitamin D level dan biochemical parameters of mothers dan 
neonates. J Diabetes Metab Disord. 12:19.

Bonds, RS., Midoro-Horiuti, T. 2013. Estrogen effects in allergy dan asthma. Curr Opin Allergy Clin Immunol, 13(1): 92-99.

Bosse. 2009. Genetics of chronic obstructive pulmonary disease: a succinct review, future avenues dan prospective clinical applications. Pub Med. 10(4): 655-667.

Brehm, JM., Schuemann B., Fuhlbrigge AL., Hollis BW., et al. 2010. Serum vitamin D levels dan severe asthma exacerbations in the Childhood Asthma Management Program study. J Allergy Clin Immunol, 126(1): 52-8.e5.

Chinellato, I., Piazza, M., Sdanri, M., Peroni, D., Piacentini, G., Boner AL. 2011. Vitamin D serum levels dan markers of asthma control in Italian children. $J$ Pediatr. 158(3): 437-41.

Compston, J.E. 1978. Hepatic osteodystrophy: vitamin D metabolism in patients with liver disease. Gut, 27(9): 1073-1090.

Ernawati, S., Sdanjaja. 2011. South East Nutrition Survey.

Global Initiative for Asthma (GINA), 2015. Global Strategy for Asthma Management \& Prevention (Update).

Gough, H., Goggins, T., Bisessar, A., Baker, M., et al. 1986. A Comparative Study of The Relative Influence of Different Anticonvulsant Drugs, UV Exposure dan Diet on Vitamin Ddan Calcium Metabolism in Out-Patients with Epilepsy. Q J Med, 59: 569-77.

Herr, C., Greulich, T., Koczulla, R.A., Meyer, S., Zakharkina, T., Branscheidt, M., et al. The role of vitamin $\mathrm{D}$ in pulmonary disease: COPD, asthma, infection, dan cancer. Respir Res. 12(1): 31.

Holick, M.F. 2004 Sunlight dan vitamin D for bone health dan prevention of autoimmune diseases, cancers, dan cardiovascular disease. The American Journal of Clinical Nutrition. 80: 1678S-1688.

Holick, M.F. 2010. The vitamin D solution: $a$ 3-step strategy to cure our most common health problem. New York: Hudson Street Press; p. 336.

Jacobsen, R,, Thorsen, S.U., Cohen A.S., Lundqvist, M., et al. 2016. Neonatal vitamin D status is not associated with later risk of type 1 diabetes: results from two large Danish population-based studies. Diabetologia, 59(9): 1871-81.

Kelly, H.W., Sorkness, C. 2011. Astma in Dipiro. Pharmacotherapy: A Pathofisiologic Approach, 8th edition, McGraw-Hill, New York. US.

Kolokotroni, O., Papadopoulou, A., Middleton, N., Kouta, C., Raftopoulos, V., et al. 2015. Vitamin D levels dan status amongst asthmatic dan non-asthmatic adolescents in Cyprus: a comparative cross-sectional study. BMC Public Health, 15: 48.

Lange, N., Litonjua, A., Hawrylowicz, C.M., Weiss, S. 2009. Vitamin D, the immune system dan asthma. Expert Rev Clin Immunol. 2009 Nov; 5(6): 693-702.

Li, F., Peng, M., Jiang, L., Sun, Q., Zhang K., Lian F., et al. 2011b. Vitamin D deficiency is associated with decreased lung function in Chinese adults with asthma. Respiration 81, 469-475 10.1159/000322008

Lorensia, A., Canggih, B,, Wijaya, R.I. 2013a. Analisa Adverse Drug Reactions pada Pasien Asma di Suatu Rumah Sakit, Surabaya, Jurnal Farmasi Indonesia, 6(3): 142-150.

Lorensia, A., Wahjuningsih, E., Supriadi. 2012. Keamanan Penggunaan Aminofilin pada Pengobatan Asma di Rumah Sakit, Jurnal Farmasi Klinik Indonesia, 1(4): 154-161.

Lorensia, A., Wijaya, R.I., Canggih, B. $2013^{\text {b }}$. Studi Efektifitas Biaya terkait Pemilihan Obat Asma Bronkiale Rawat Inap di Suatu Rumah Sakit Swasta di Surabaya. Jurnal Ilmiah Sains \& Teknologi, 7(1): 56-63.

Lorensia, A., Wahjuningsih, E., Canggih B., Lisiska, N. 2011. Pharmacist's Strategies in Treating Asthma Bronchiale Outpatient. Jurnal of Tropical Pharmacy dan 
Chemistry (UNMUL), 1(3): 177-191.

Maalmi, H., Berraïes, A., Tangour, E., Ammar, J., et al. 2012. The impact of vitamin $\mathrm{D}$ deficiency on immune T cells in asthmatic children: a case-control study. J Asthma Allergy, 5: 11-9.

Mahon, B.D., Gordon, S.A., Cruz, J., Cosman, F., Cantorna, M.T. et al. 2003. Cytokine profile in patients with multiple sclerosis following vitamin D supplementation. J Neuroimmunol., 134(1-2): 128-32.

McDuffie, J.R., Calis, K.A., Booth, S.L., Uwaifo, G.I., Yanovski, J.A. 2002. Effects of orlistat on fat-soluble vitamins in obese adolescents. Pharmacotherapy, 22(7): 814-22.

Murray, RK., Granner, D.K., Mayes, P.A., Rodwell, V.W. 2014. Biokimia Harper. Jakarta: EGC. 25: 616-618.

Naing, L., Win, T., Rusli, B.N. 2008. Medical Statistic: Practical Issues in Calculating the Sample Size for Prevence Studies, Archives of Orofacial Sciences 2006; 1 : 9-14.

National Center for Chronic Disease Prevention dan Health Promotion. 2011, Data Source with Asthma Content: Behavioral Risk Factor Surveillance System (BRFSS).

NHLBI. 2007. Guidelines for the Diagnosis dan Management of Asthma (EPR-3) NIH (online).

Niruban, S.J., Alagiakrishnan, K., Beach, J., Senthilselvan, A. 2015. Association between vitamin D dan respiratory outcomes in Canadian adolescents dan adults. J Asthma., 52(7): 653-61.

Oemiati, R., Sihombing M., adn Qomariah. 2010. Faktor-faktor yang berhubungan dengan penyakit asma di Indonesia. Media Litbang Kesehatan. XX(1): 41-49.

Park, C.Y., Hill, K.M., Elble, A.E., et al. 2010. Daily Supplementation with 25 mu g Cholecalciferol Does Not Increase Calcium Absorption or Skeletal Retention in Adolescent Girls with Low Serum 25-
Hydroxyvitamin D. Journal of Nutrition. 2010; 140: 2139-2144.

PDPI (Perhimpunan Dokter Paru Indonesia). 2004. PPOK (Penyakit Paru obstruksi Kronik). Pedoman Praktis Diagnosis dan Penatalaksanaan di Indonesia.

Plum, L.A., DeLuca, H. The functional metabolism dan molecular biology of vitamin D action. In: Holick MF, editor., ed. Vitamin D: Physiology, Molecular Biology, dan Clinical Applications. 2nd ed. New York, NY: Humana Press; 2010: 61-97.

Reeder, A., Hurst, P.V. 2012. Consensus Statement on Vitamin D dan Sun Exposure in New Zealdan. Wellington: Ministry of Health.

RISKESDAS. 2008. Laporan Riset Kesehatan Daerah (RISKESDAS) 2007. Litbang Depkes.

Ross, A.C., Taylor, C.L., Yaktine, A.L., Valle, H.B.D. 2011. Dietary Reference Intakes for Vitamin $D$ dan Calcium. National Academy of Sciences, Washington, D.C.

Sundberg, R., Toren, K., Franklin, K.A., Gislason, T., et al. 2010. Asthma in men dan women: Treatment adherence, anxiety, dan quality of sleep. Respiratory Medicine, 104(3):337-344.

Sutherldan, E.R., Goleva, E., Jackson, L.P., Stevens, A.D., Leung, DY. 2010. Vitamin D levels, lung function, dan steroid response in adult asthma. Am J Respir Crit Care Med. 2010;181: 699-704.

Tamašauskienè, L., Gasiūnienè, E., Lavinskienè, S., Sakalauskas, R., Šitkauskienè, B. 2015. Evaluation of vitamin D levels in allergic dan nonallergic asthma. Medicina 103: 1-7.

Tehrani, H.G., Mostajeran, F., Shahsavari S. 2014. The effect of calcium dan vitamin D supplementation on menstrual cycle, body mass index dan hyperdanrogenism state of women with poly cystic ovarian syndrome. J Res Med Sci. 19(9): 875880. 
Tsiaras, W.G., Weinstock, M.A. 2011. Factors influencing vitamin D status. Acta Derm Venereol., 91(2): 115-24.

Verdoia, M., Schaffer, A., Barbieri, L., Di Giovine, G., et al. 2015. Impact of gender difference on vitamin D status dan its relationship with the extent of coronary artery disease. Nutr Metab Cardiovasc Dis., 25(5): 464-70.

Weiss, S.T., Litonjua, A.A. 2011. The in utero effects of maternal vitamin D deficiency: how it results in asthma dan other chronic diseases. Am J Respir Crit Care Med. 15;183(10): 1286-7.

WHO. 2003. Prevention of Allergy dan Allergic Asthma - World Health Organization (online).

Williams, A.F., Aggett, P., Danerson, A.S., Fraser, R. 2007. Update on Vitamin D: Position statement by the Scientific Advisory Committee on Nutrition. The Stationery Office. 